

\title{
Auxin-like effect of derivatives of Pyrimidine, Pyrazole, Isoflavones, Pyridine, Oxazolopyrimidine and Oxazole on acceleration of Vegetative growth of Flax
}

\author{
Tsygankova V. A. ${ }^{1 *}$, Andrusevich Ya.V. ${ }^{1}$, Shtompel O.I. ${ }^{1}$, Shablykin O.V. ${ }^{1}$, \\ Hurenko A. O. ${ }^{1}$, Solomyanny R.M. ${ }^{1}$, Mrug G.P. ${ }^{1}$, Frasinyuk M.S. ${ }^{1}$, \\ Pilyo S.G. ${ }^{1}$, Kornienko A.M. ${ }^{1}$, Brovarets V.S. ${ }^{1}$ \\ ${ }^{1}$ Department for Chemistry of Bioactive Nitrogen-Containing Heterocyclic \\ Compounds, Institute of Bioorganic Chemistry and Petrochemistry, National Academy \\ of Sciences of Ukraine, 1, Murmanskaya str., 02660, Kyiv, Ukraine
}

\begin{abstract}
The comparative analysis of the stimulating effect of low molecular weight heterocyclic compounds, derivatives of pyrimidine, pyrazole, isoflavones, pyridine, oxazolopyrimidine, oxazole and plant hormones auxins IAA ( $1 H$-Indol-3-ylacetic acid) and NAA (1-Naphthylacetic acid) on germination of seeds and growth of seedlings of flax (Linum usitatissimum L.) cultivars Ukrainian 3 and Svitanok was conducted. The specific auxin-like stimulating effect of chemical heterocyclic compounds on the basic processes of flax seedlings growth: cell division, cell proliferation, cell elongation and cell differentiation was found. The growth parameters of flax seedlings grown on water solution of chemical heterocyclic compounds used at the concentrations $10^{-8} \mathrm{M}$ and $10^{-9} \mathrm{M}$ were similar or higher of the growth parameters of flax seedlings grown on distilled water (control) or on water solution of auxins IAA and NAA used at the same concentrations $10^{-8} \mathrm{M}$ and $10^{-9} \mathrm{M}$. The obtained results proved the possibility of practical application of derivatives of pyrimidine, pyrazole, isoflavones, pyridine, oxazolopyrimidine and oxazole for intensification of vegetative growth of flax.
\end{abstract}

Keywords: Linum usitatissimum L., auxins IAA and NAA, pyrimidine, pyrazole, isoflavones, pyridine, oxazolopyrimidine, oxazole.

\section{Introduction}

Flax (Linum usitatissimum L.) is one of the important oil and fiber crops cultivated in more than 20 world countries ${ }^{1,3}$. Flax is widely used to produce cellulosic fiber for textile and paper industry and seed oil for food, cosmetic and pharmaceutical industry ${ }^{3-5}$. Flax seed lignan secoisolariciresinol diglucoside (SDG) and seed oil which contains more than $50 \%$ of omega- 3 fatty acid- $\alpha$-linolenic acid (ALA), sterols and tocopherols are used as supplements to dietary food and as pharmaceutical drugs for treatment of different

International Journal of PharmTech Research, 2018,11(3): 274-286. 
diseases: weight gain, heart disease, hypertension, atherosclerosis, diabetes, arthritis, memory problems, depression, cancer, inflammatory diseases, kidney disorders ${ }^{3-5}$. Moreover flax oil has polymer-forming properties due to high content of linolenic acid; therefore it is an ideal raw material for manufacture of paints, varnishes and ink ${ }^{4,6,7}$.

During the last decades the plant growth regulators of natural or synthetic origin, organic and mineral fertilizers, and vitamins are widely used in the agricultural and biotechnological practice to improve the growth and development of flax during vegetative stage ${ }^{8-13}$. The new promising approach is elaboration of new plant growth regulators having specific to flax (Linum usitatissimum L.) activity and lack of toxic effect for environment, animal and human health. In recent years the considerable attention is focused on practical application in the agriculture of different classes of low molecular weight heterocyclic compounds, derivatives of pyrimidine, pyrazole, isoflavones, pyridine, oxazole, oxazolopyrimidine as effective substitutes of traditional plant growth regulators, herbicides, fungicides and antimicrobial agents ${ }^{14-26}$. Testing of different classes of chemical low molecular weight heterocyclic compounds on human and animal cells indicated their activity against cancer, viral, bacterial, fungal, infectious, inflammatory and nervous diseases ${ }^{27-31}$.

Today the new low molecular weight five and six-membered heterocyclic compounds that exhibit a wide range of biological activity on human and animal cells are synthesized in the Institute of Bioorganic Chemistry and Petrochemistry of National Academy of Sciences of Ukraine ${ }^{32-39}$. Our previously conducted screening of new effective plant growth regulating substances among different classes of chemical low molecular weight heterocyclic compounds showed that most tested chemical heterocyclic compounds revealed a high stimulating effect on growth and development of various agricultural crops during vegetative stage ${ }^{40-44}$. We found also that some low molecular weight heterocyclic compounds, derivatives of pyridine, pyrimidine, pyrazole and isoflavones showed a high stimulating effect on organogenesis of shoots and roots in the isolated tissue cultures of flax (Linum usitatissimum L.) cultivar heavenly grown under in vitro conditions ${ }^{45}$. Based on the results of our numerous researchers the elaboration of new effective regulators on the base of different classes of chemical low molecular weight heterocyclic compounds for improving of vegetative growth of flax (Linum usitatissimum L.) is very promising approach.

The main task of the present work was study of the stimulating effect of chemical low molecular weight heterocyclic compounds, derivatives of pyrimidine, pyrazole, isoflavones, pyridine, oxazolopyrimidine and oxazole in comparison with the stimulating effect of plant hormones auxins IAA $(1 \mathrm{H}$-Indol-3-ylacetic acid) and NAA (1-Naphthylacetic acid) on growth of seedlings of flax (Linum usitatissimum L.) cultivars Ukrainian 3 and Svitanok.

\section{Materials and methods}

\subsection{Plant treatment and growing conditions}

The seeds of flax (Linum usitatissimum L.) cultivars Ukrainian 3 and Svitanok were surface sterilized by $1 \% \mathrm{KMnO}_{4}$ solution for $3 \mathrm{~min}$ followed by treatment with $96 \%$ ethanol solution for $1 \mathrm{~min}$, and then washed three times with sterile distilled water. After this procedure wheat seeds were placed in the cuvettes (each containing 20-25 seeds) on the perlite moistened with distilled water (control), or with solution of chemical heterocyclic compounds, derivatives of pyrimidine, pyrazole, isoflavones, pyridine, oxazolopyrimidine, oxazole used at the concentrations $10^{-8} \mathrm{M}$ and $10^{-9} \mathrm{M}$ or plant hormones auxins IAA $\left(1 \mathrm{H}^{-}\right.$ Indol-3-ylacetic acid) and NAA (1-Naphthylacetic acid) used at the same concentrations $10^{-8} \mathrm{M}$ and $10^{-9} \mathrm{M}$. Afterward, the control and experimental flax seeds were placed in the thermostat for their germination in the darkness at the temperature $25{ }^{\circ} \mathrm{C}$ during 48 hours. Sprouted flax seedlings were placed in the growth chamber where seedlings were grown for 15 days (flax cultivar Ukrainian 3) or 20 days (flax cultivar Svitanok) at the $16 / 8 \mathrm{~h}$ light/dark conditions, at the temperature $24{ }^{\circ} \mathrm{C}$, light intensity $3000 \mathrm{lux}$ and air humidity $60-80 \%$. The comparative analysis of the growth parameters of the flax seedlings (i.e. number of germinated seeds $(\%)$, length of shoots $(\mathrm{cm})$, total number of roots (pcs), total length of roots (mm)) was carried out on the $15^{\text {th }}$ or $20^{\text {th }}$ days after their sprouting according to the guideline ${ }^{46}$.

\subsection{Statistical analysis}

All experiments were performed in three replicates. Statistical analysis of the data was performed using dispersive Student's-t test with the level of significance at $\mathrm{P} \leq 0.05$, the values are mean $\pm \mathrm{SD}^{47}$. 


\section{Results and Discussion}

3.1. Study of stimulating effect of derivatives of pyrimidine, pyrazole, isoflavones and pyridine on growth of flax (Linum usitatissimum L.) cultivar Ukrainian 3

The comparative analysis of stimulating effect of plant hormones auxins IAA and NAA, and chemical heterocyclic compounds, derivatives of pyrimidine, pyrazole, isoflavones and pyridine on growth of flax (Linum usitatissimum L.) seedlings cultivar Ukrainian 3 was conducted.

The chemical structure, chemical name and molecular mass (MM) of plant hormones auxins IAA (1H-Indol-3-ylacetic acid) and NAA (1-Naphthylacetic acid), and tested chemical heterocyclic compounds, derivatives of pyrimidine (compound № 1), pyrazole (compounds № 2 and № 3), isoflavones (compound № 4) and pyridine (compound № 5) are shown in the Table 1.

Table 1: Chemical structure of plant hormones and chemical heterocyclic compounds, derivatives of pyrimidine, pyrazole, isoflavones and pyridine

\begin{tabular}{|l|l|l|}
\hline IAn & \multicolumn{1}{c|}{$\begin{array}{c}\text { Chemical name and } \\
\text { relative molecular mass of compounds }\end{array}$} \\
\hline $\mathbf{2}$ & IAA (1H-Indol-3-ylacetic acid), MM 175.19 \\
\hline $\mathbf{2}$ & NAA (1-Naphthylacetic acid), MM 186.21 \\
\hline $\mathbf{3}$ & & \\
\hline
\end{tabular}




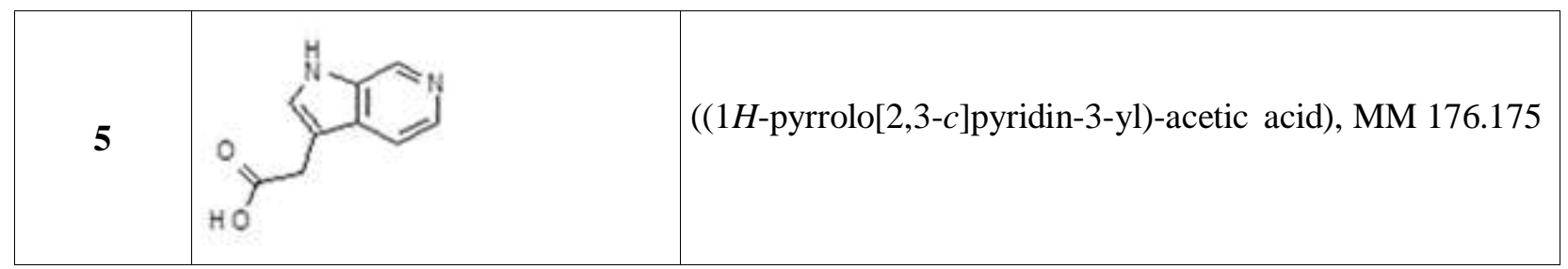

It was found that all chemical heterocyclic compounds used at the concentration of $10^{-8} \mathrm{M}$ showed auxin-like stimulating effect on growth and development of shoot and root system of the flax seedlings during 15 days (Figure 1, $\mathrm{A}$ and $\mathrm{B}$ ).

A



B

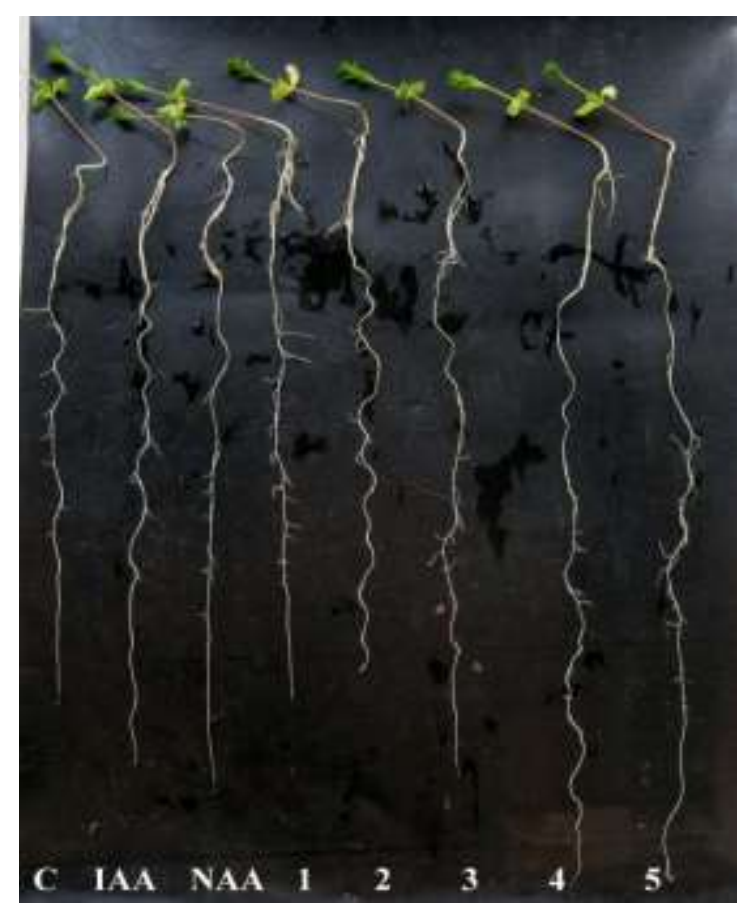

Figure 1: Stimulating effect of auxins IAA (1H-Indol-3-ylacetic acid) and NAA (1-Naphthylacetic acid) and chemical heterocyclic compounds, derivatives of pyrimidine (compound №1 - 6-Methanesulfonylimidazo[1,2-a]pyrimidine-5-ylamine), pyrazole (compound №2 - 5-Hydrazino-1-phenyl-1H-pyrazole-4carbohydrazide and compound №3 - 3-Ethyl-7-methyl-3,7-dihydro-4H-pyrazolo[3,4-d][1,2,3]triazin-4one), isoflavones (compound №4 - 5-Hydroxy-7-methoxy-8-(methoxymethyl)-3-(4-methoxyphenyl)-4Hchromen-4-one), pyridine (compound №5 - ((1H-pyrrolo[2,3-c]pyridin-3-yl)-acetic acid) on growth and development of shoot system (A) and root system (B) of the $15^{\text {th }}$-day-old flax seedlings cultivar Ukrainian 3 as compared to control (C) flax seedlings grown on the distilled water 
The comparative analysis of the biometric indices (i.e. number of germinated seeds (\%), length of shoots $(\mathrm{cm})$, total number of roots $(\mathrm{pcs})$, total length of roots $(\mathrm{mm}))$ showed that the biometric indices of $15^{\text {th }}$ day-old flax seedlings cultivar Ukrainian 3 grown on water solution of heterocyclic compounds, derivatives of pyrimidine, pyrazole, isoflavones and pyridine used at the concentration $10^{-8} \mathrm{M}$ were higher of the biometric indices of flax seedlings grown on water solution of auxins IAA and NAA used at the same concentration $10^{-}$ ${ }^{8} \mathrm{M}$ and control flax seedlings grown on distilled water in average: according with length of shoots - at the 5-7 $\%$ as compared with control; according with total length of roots - at the 15-58 \%, 3-20\%, 11-15\% as compared with control, IAA, and NAA, respectively; according with total number of roots - at the 39-67\% as compared with control (Figure 2).

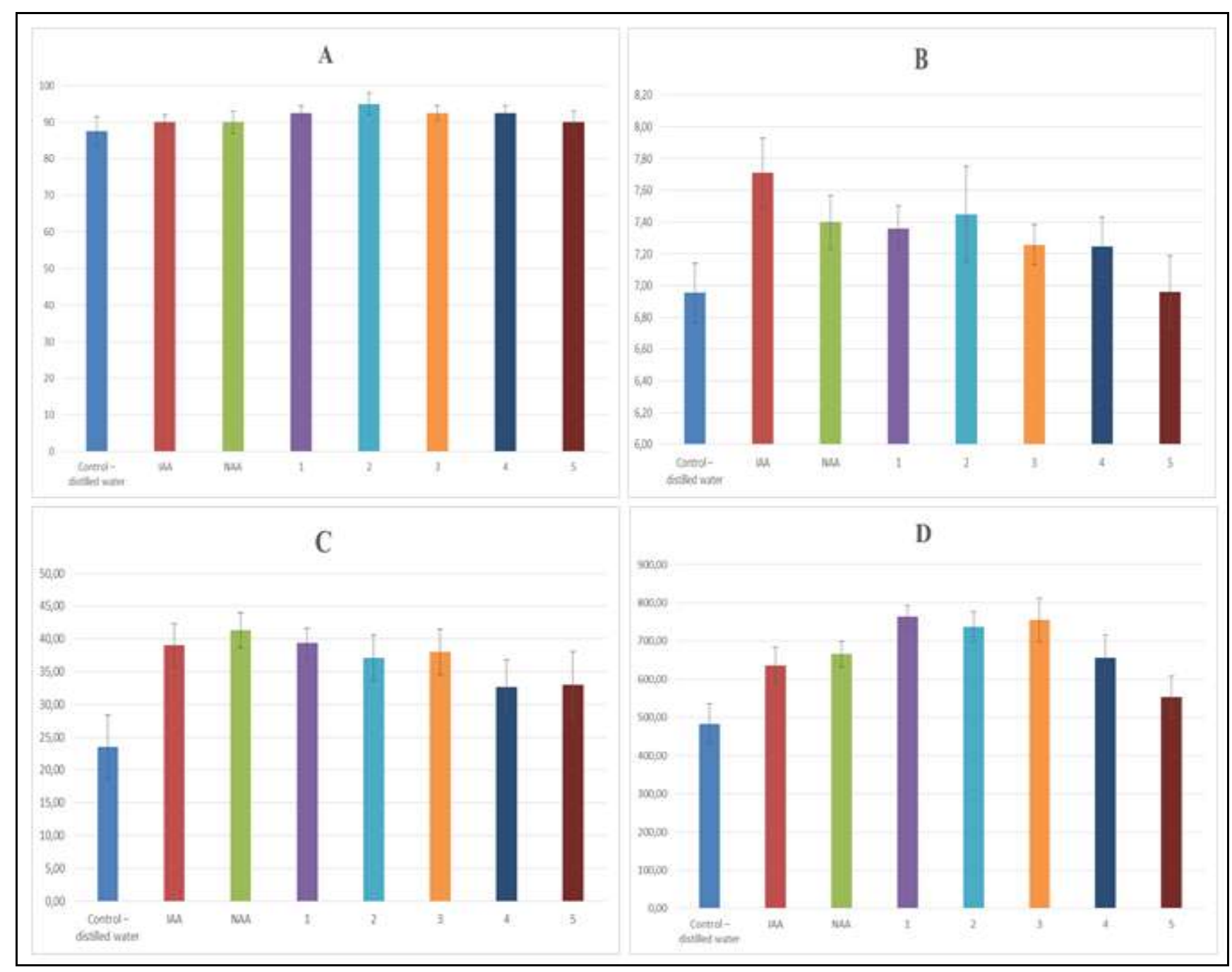

Figure 2: Stimulating effect of auxins IAA (1H-Indol-3-ylacetic acid) and NAA (1-Naphthylacetic acid) and chemical heterocyclic compounds, derivatives of pyrimidine (compound №1 - 6-Methanesulfonylimidazo[1,2-a]pyrimidine-5-ylamine), pyrazole (compound №2 - 5-Hydrazino-1-phenyl-1H-pyrazole-4carbohydrazide and compound №3 - 3-Ethyl-7-methyl-3,7-dihydro-4H-pyrazolo[3,4-d][1,2,3]triazin-4one), isoflavones (compound №4 - 5-Hydroxy-7-methoxy-8-(methoxymethyl)-3-(4-methoxyphenyl)-4Hchromen-4-one), pyridine (compound №5 - ((1H-pyrrolo[2,3-c]pyridin-3-yl)-acetic acid) on biometric indices of the $15^{\text {th }}$-day-old flax seedlings cultivar U krainian 3. A - number of germinated seeds (\%), B length of shoots $(\mathrm{cm}), \mathrm{C}$ - total number of roots (pcs), D - total length of roots $(\mathrm{mm})$. Control - flax seedlings grown on the distilled water

Particularly it was found that the biometric indices of flax seedlings grown on $10^{-8} \mathrm{M}$ water solution of compound №1 - 6-Methanesulfonyl-imidazo[1,2-a]pyrimidine-5-ylamine were higher of the biometric indices of flax seedlings grown either on distilled water (control) or on $10^{-8} \mathrm{M}$ water solution of auxins IAA and NAA 
in average: according with length of shoots - at the $6 \%$ as compared with control; according with total length of roots - at the $58 \%, 20 \%$, and $15 \%$ as compared with control, IAA and NAA, respectively; according with total number of roots - at the $67 \%$ as compared with control (Figure 2).

The biometric indices of flax seedlings grown on $10^{-8} \mathrm{M}$ water solution of compound №2 - 5Hydrazino-1-phenyl-1 $H$-pyrazole-4-carbohydrazide, were higher of the biometric indices of flax seedlings grown either on distilled water (control) or on $10^{-8} \mathrm{M}$ water solution of auxins IAA and NAA in average: according with length of shoots - at the $7 \%$ as compared with control; according with total length of roots at the $53 \%, 16 \%$, and $11 \%$ as compared with control, IAA and NAA, respectively; according with total number of roots - at the $58 \%$ as compared with control (Figure 2).

The biometric indices of flax seedlings grown on $10^{-8} \mathrm{M}$ water solution of compound №3 - 3-Ethyl-7methyl-3,7-dihydro-4H-pyrazolo[3,4- $d][1,2,3]$ triazin-4-one, were higher of the biometric indices of flax seedlings grown either on the distilled water (control) or on $10^{-8} \mathrm{M}$ water solution of auxins IAA and NAA in average: according with length of shoots - at the $5 \%$ as compared with control; according with total length of roots - at the $56 \%, 19 \%$, and $13 \%$ as compared with control, IAA and NAA, respectively; according with total number of roots - at the $61 \%$ as compared with control (Figure 2).

The biometric indices of flax seedlings grown on $10^{-8} \mathrm{M}$ water solution of compound №4 - 5Hydroxy-7-methoxy-8-(methoxymethyl)-3-(4-methoxyphenyl)-4H-chromen-4-one, were higher of the biometric indices of flax seedlings grown either on the distilled water (control) or on $10^{-8} \mathrm{M}$ water solution of auxins IAA and NAA in average: according with length of shoots - at the $5 \%$ as compared with control; according with total length of roots - at the $36 \%$ and $3 \%$ as compared with control and IAA, respectively; according with total number of roots - at the $39 \%$ as compared with control (Figure 2).

The biometric indices of flax seedlings grown on $10^{-8} \mathrm{M}$ water solution of compound №5 - $((1 \mathrm{H}$ pyrrolo[2,3-c]pyridin-3-yl)-acetic acid), were higher than the biometric indices of flax seedlings grown either on the distilled water (control) or on $10^{-8} \mathrm{M}$ water solution of auxins IAA and NAA in average: according with total length of roots - at the $15 \%$ as compared with control; according with total number of roots - at the 40 $\%$ as compared with control (Figure 2).

Thus, the obtained results testified that all tested chemical heterocyclic compounds derivatives of pyrimidine, pyrazole, isoflavones and pyridine showed auxin-like stimulating effect on growth of shoot and root systems of the $15^{\text {th }}$-day-old seedlings of flax (Linum usitatissimum L.) cultivar Ukrainian 3. Obviously, that auxin-like growth stimulating effect of the chemical heterocyclic compounds is explained by their inducing action on plant cell elongation, proliferation and differentiation that are the basic processes of plant growth and development ${ }^{48-53}$.

\subsection{Study of stimulating effect of derivatives of oxazolopyrimidine and oxazole on growth of flax (Linum usitatissimum L.) cultivar Svitanok}

The comparative analysis of stimulating effect of plant hormones auxins IAA and NAA, and chemical heterocyclic compounds, derivatives of oxazolopyrimidine and oxazole on growth of the flax (Linum usitatissimum L.) seedlings cultivar Svitanok was conducted.

The chemical structure, chemical name and molecular mass (MM) of plant hormones auxins IAA (1H-Indol-3-ylacetic acid) and NAA (1-Naphthylacetic acid), and tested chemical heterocyclic compounds, derivatives of oxazolopyrimidine (compounds № 1-4) and oxazole (compounds № 5 and 6) are shown in the Table 2. 
Table 2: Chemical structure of plant hormones and chemical heterocyclic compounds, derivatives of oxazolopyrimidine and oxazole

\begin{tabular}{|c|c|c|}
\hline № & $\begin{array}{l}\text { Chemical structure of } \\
\text { compounds }\end{array}$ & $\begin{array}{l}\text { Chemical name and } \\
\text { relative molecular mass of compounds }\end{array}$ \\
\hline IAA & & IAA ( $1 H$-Indol-3-ylacetic acid), MM 175.19 \\
\hline NAA & & NAA (1-Naphthylacetic acid), MM 186.21 \\
\hline 1 & & $\begin{array}{l}\text { 7-Amino-2,5-diphenyl }[1,3] \text { oxazolo }[5,4-d] \text { pyrimidine, } \\
\text { MM } 288.31\end{array}$ \\
\hline 2 & & $\begin{array}{l}\text { 2,5-Diphenyl }[1,3] \text { oxazolo }[5,4-d] \text { pyrimidin-7 }(6 H) \text {-one, } \\
\text { MM } 289.30\end{array}$ \\
\hline 3 & & $\begin{array}{l}\text { 5-(4-Ethylphenyl)-2-phenyl[1,3]oxazolo[5,4- } d] \\
\text { pyrimidin-7(6H)-one, MM } 317.35\end{array}$ \\
\hline 4 & & $\begin{array}{l}\text { 7-Amino-5-(4-ethylphenyl)-2-phenyl[1,3] oxazolo[5,4- } \\
d] \text { pyrimidine, MM } 316.37\end{array}$ \\
\hline 5 & & $\begin{array}{l}\text { 2-Phenyl-5-(piperidin-1-ylsulfonyl)-1,3-oxazole-4- } \\
\text { carbonitrile, MM 317.37 }\end{array}$ \\
\hline 6 & & $\begin{array}{l}\text { 2-Tolyl-5-(piperidin-1-ylsulfonyl)-1,3-oxazole-4- } \\
\text { carbonitrile, MM } 331.40\end{array}$ \\
\hline
\end{tabular}


It was found that chemical heterocyclic compounds used at the concentration $10^{-9} \mathrm{M}$ showed auxinlike stimulating effect on growth and development of shoot and root system of the flax seedlings during 20 days (Figure 3).

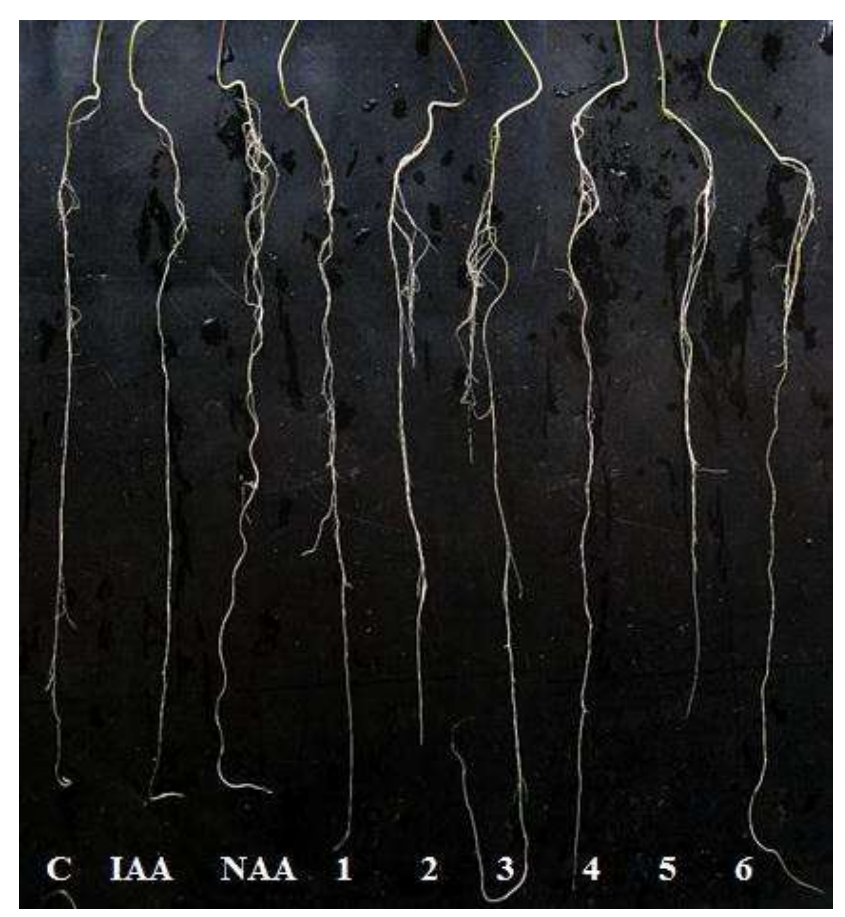

Figure 3: Stimulating effect of auxins IAA (1H-Indol-3-ylacetic acid) and NAA (1-Naphthylacetic acid), and chemical heterocyclic compounds, derivatives of oxazolopyrimidine (compound №1 - 7-amino-2,5diphenyl $[1,3]$ oxazolo [5,4- $d]$ pyrimidine, compound №2 - 2,5-diphenyl $[1,3]$ oxazolo $[5,4-d]$ pyrimidin-7(6H)one, compound №3 - 5-(4-ethylphenyl)-2-phenyl[1,3]oxazolo[5,4- $d]$ pyrimidin-7(6H)-one, compound №4 - 7-amino-5-(4-ethylphenyl)-2-phenyl[1,3]oxazolo[5,4-d]pyrimidine) and oxazole (compound №5 2-phenyl-5-(piperidin-1-ylsulfonyl)-1,3-oxazole-4-carbonitrile and compound №6 - 2-tolyl-5-(piperidin1-ylsulfonyl)-1,3-oxazole-4-carbonitrile) on growth of root system of the $20^{\text {th }}$-day-old flax seedlings cultivar Svitanok as compared to control (C) flax seedlings grown on the distilled water

The comparative analysis of the biometric indices (i.e. number of germinated seeds (\%), length of shoots $(\mathrm{cm})$, total number of roots (pcs), total length of roots $(\mathrm{mm})$ ) showed that the biometric indices of $20^{\text {th }}$ day-old flax seedlings cultivar Svitanok grown on water solution of heterocyclic compounds, derivatives of oxazolopyrimidine and oxazole used at the concentration $10^{-9} \mathrm{M}$ were higher of the biometric indices of flax seedlings grown on water solution of auxins IAA and NAA used at the same concentration $10^{-9} \mathrm{M}$ and control flax seedlings grown on distilled water in average: according with length of shoots - at the 11-14 \%, 13-16\% and 21-24 \% as compared with control, IAA, and NAA, respectively; according with total length of roots - at the 24-80 \%, 15-35\%, and 10-68 \% as compared with control, IAA, and NAA, respectively; according with total number of roots - at the 28-79 \%, 14-27\%, and 5-12\% as compared with control, IAA, and NAA, respectively (Figure 4). 


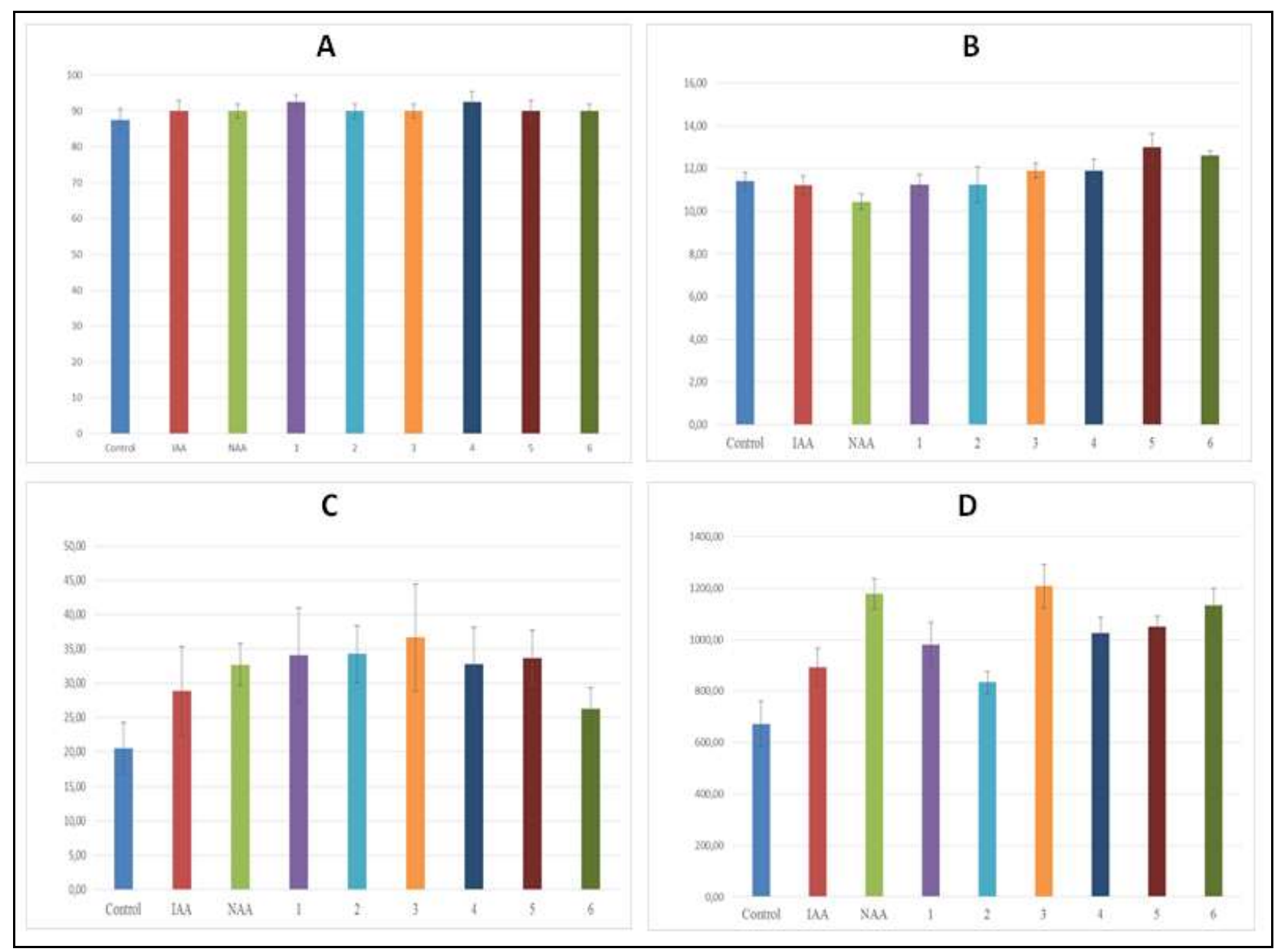

Figure 4: Stimulating effect of auxins IAA (1H-Indol-3-ylacetic acid) and NAA (1-Naphthylacetic acid) and chemical heterocyclic compounds, derivatives of oxazolopyrimidine (compound №1 - 7-amino-2,5diphenyl $[1,3]$ oxazolo $[5,4-d]$ pyrimidine, compound №2 - 2,5-diphenyl $[1,3]$ oxazolo $[5,4-d]$ pyrimidin-7(6H)one, compound №3 - 5-(4-ethylphenyl)-2-phenyl[1,3]oxazolo $[5,4-d]$ pyrimidin-7(6H)-one, compound №4 - 7-amino-5-(4-ethylphenyl)-2-phenyl[1,3] oxazolo[5,4- $d]$ pyrimidine) and oxazole (compound №5 2-phenyl-5-(piperidin-1-ylsulfonyl)-1,3-oxazole-4-carbonitrile and compound №6 - 2-tolyl-5-(piperidin1-ylsulfonyl)-1,3-oxazole-4-carbonitrile) on biometric indices of the $20^{\text {th }}$-day-old flax seedlings cultivar Svitanok. A - number of germinated seeds $(\%), B$ - length of shoots $(\mathrm{cm}), \mathrm{C}$ - total number of roots (pcs), D - total length of roots ( $\mathrm{mm})$, Control - flax seedlings grown on the distilled water

Particularly it was found that the biometric indices of flax seedlings grown on $10^{-9} \mathrm{M}$ water solution of compound №1 - 7-amino-2,5-diphenyl[1,3]oxazolo[5,4- $d$ ]pyrimidine were higher of the biometric indices of flax seedlings grown either on distilled water (control) or on $10^{-9} \mathrm{M}$ water solution of auxins IAA and NAA in average: according with total length of shoots - at the $46 \%, 10 \%$ as compared with control and IAA, respectively; according with total number of roots - at the $66 \%, 18 \%$ and $4 \%$ as compared with control, IAA and NAA, respectively (Figure 4).

The biometric indices of flax seedlings grown on $10^{-9} \mathrm{M}$ water solution of compound №2 - 2,5diphenyl[1,3] oxazolo[5,4- $d$ ]pyrimidin-7 $(6 H)$-one were higher of the biometric indices of flax seedlings grown either on the distilled water (control) or on $10^{-9} \mathrm{M}$ water solution of auxins IAA and NAA in average: according with total length of roots - at the $24 \%$ as compared with control; according with total number of roots - at the $66 \%, 18 \%$ and $4 \%$ as compared with control, IAA and NAA, respectively (Figure 4).

The biometric indices of flax seedlings grown on $10^{-9} \mathrm{M}$ water solution of compound №3 - 5-(4ethylphenyl)-2-phenyl[1,3] oxazolo[5,4- $d]$ pyrimidin-7(6H)-one were higher of the biometric indices of flax 
seedlings grown either on distilled water (control) or on $10^{-9} \mathrm{M}$ water solution of auxins IAA and NAA in average: according with total length of roots - at the $80 \%, 35 \%$ and $3 \%$ as compared with control, IAA and NAA, respectively; according with total number of roots - at the $79 \%, 27 \%$ and $12 \%$ as compared with control, IAA and NAA, respectively (Figure 4).

The biometric indices of flax seedlings grown on $10^{-9} \mathrm{M}$ water solution of compound №4 - 7amino-5-(4-ethylphenyl)-2-phenyl[1,3] oxazolo[5,4- $d$ ]pyrimidine were higher of the biometric indices of flax seedlings grown either on distilled water (control) or on $10^{-9} \mathrm{M}$ water solution of auxins IAA and NAA in average: according with total length of roots - at the $53 \%$ and $15 \%$ as compared with control and IAA, respectively; according with total number of roots - at the $60 \%$ and $14 \%$ as compared with control and IAA, respectively (Figure 4).

The biometric indices of flax seedlings grown on $10^{-9} \mathrm{M}$ water solution of compound №5 - 2phenyl-5-(piperidin-1-ylsulfonyl)-1,3-oxazole-4-carbonitrile were higher of the biometric indices of flax seedlings grown either on distilled water (control) or on $10^{-9} \mathrm{M}$ water solution of auxins IAA and NAA in average: according with length of shoots - at the $14 \%, 16 \%$ and $24 \%$ as compared with control, IAA and NAA, respectively; according with total length of roots - at the $56 \%$ and $18 \%$ as compared with control and IAA, respectively; according with total number of roots - at the $64 \%$ and $17 \%$ as compared with control and IAA, respectively (Figure 4).

The biometric indices of flax seedlings grown on $10^{-9} \mathrm{M}$ water solution of th e compound №6 - 2tolyl-5-(piperidin-1-ylsulfonyl)-1,3-oxazole-4-carbonitrile) were higher of the biometric indices of flax seedlings grown either on distilled water (control) or on $10^{-9} \mathrm{M}$ water solution of the auxins IAA and NAA in average: according with length of shoots - at the $11 \%, 13 \%$ and $21 \%$ as compared with control, IAA and NAA, respectively; according with total length of roots - at the $68 \%$ and $27 \%$ as compared with control and IAA, respectively; according with total number of roots - at the $28 \%$ as compared with control (Figure 4).

It was found that the growth stimulating effect of all tested heterocyclic compounds depended on the various substituents in the chemical structure of heterocyclic compounds. The highest effect revealed the compound №3 - 5-(4-ethylphenyl)-2-phenyl[1,3]oxazolo[5,4- $d$ ]pyrimidin-7(6H)-one containing 4-ethylphenyl substituent at the $5^{\text {th }}$ position and oxygen at the $7^{\text {th }}$ position of pyrimidine fragment and the compound №5 - 2phenyl-5-(piperidin-1-ylsulfonyl)-1,3-oxazole-4-carbonitrile containing phenyl substituent at the $2^{\text {th }}$ position of oxazole.

At the same time the lower growth stimulating effect revealed the compounds: the compound №1 - 7amino-2,5-diphenyl[1,3] oxazolo[5,4- $d]$ pyrimidine containing amino group at the $7^{\text {th }}$ position of pyrimidine fragment, the compound №2 - 2,5-diphenyl[1,3] oxazolo[5,4-d]pyrimidin-7(6H)-one containing phenyl substituent at the $5^{\text {th }}$ position of pyrimidine fragment, the compound №4 - 7-amino-5-(4-ethylphenyl)-2phenyl[1,3]oxazolo[5,4- $d$ ]pyrimidine containing amino group at the $7^{\text {th }}$ position of pyrimidine fragment, and the compound №6 - 2-tolyl-5-(piperidin-1-ylsulfonyl)-1,3-oxazole-4-carbonitrile containing tolyl substituent at the $2^{\text {th }}$ position of oxazole.

Possibly, that growth stimulating effect of the tested heterocyclic compounds depended on the presence of various substituents at the $5^{\text {th }}$ and $7^{\text {th }}$ positions of pyrimidine fragment in the derivatives of oxazolopyrimidine (compounds №1-4) and different substituents at the $2^{\text {th }}$ position of oxazole in the derivatives of oxazole (compounds №5 and №6).

\section{Conclusion}

The stimulating effect of low molecular weight heterocyclic compounds, derivatives of pyrimidine, pyrazole, isoflavones, pyridine, oxazolopyrimidine and oxazole on acceleration of vegetative growth of flax (Linum usitatissimum L.) two cultivars Ukrainian 3 and Svitanok was studied. It was shown that all classes of chemical heterocyclic compounds demonstrated auxin-like growth stimulating effect, which was similar or higher of the effect of plant hormones IAA and NAA. The biometric indices of $15^{\text {th }}$-day-old flax seedlings cultivar Ukrainian 3 grown on water solution of heterocyclic compounds, derivatives of pyrimidine, pyrazole, isoflavones and pyridine used at the concentration $10^{-8} \mathrm{M}$ were higher of the biometric indices of flax seedlings 
grown on water solution of auxins IAA and NAA used at the same concentration $10^{-8} \mathrm{M}$ and control flax seedlings grown on distilled water in average: according with length of shoots - at the 5-7 \% as compared with control; according with total length of roots - at the 15-58 \%, 3-20\%, 11-15\% as compared with control, IAA, and NAA, respectively; according with total number of roots - at the 39-67\% as compared with control. The biometric indices of $20^{\text {th }}$-day-old flax seedlings cultivar Svitanok grown on water solution of heterocyclic compounds, derivatives of oxazolopyrimidine and oxazole used at the concentration $10^{-9} \mathrm{M}$ were higher of the biometric indices of flax seedlings grown on water solution of auxins IAA and NAA used at the same concentration $10^{-9} \mathrm{M}$ and control flax seedlings grown on distilled water in average: according with length of shoots - at the 11-14 \%, 13-16\% and 21-24\% as compared with control, IAA, and NAA, respectively; according with total length of roots - at the 24-80\%, 15-35\%, and 10-68 \% as compared with control, IAA, and NAA, respectively; according with total number of roots - at the 28-79 \%, 14-27\%, and 5$12 \%$ as compared with control, IAA, and NAA, respectively. The growth stimulating effect of chemical heterocyclic compounds depended on the various substituents in the chemical structure of heterocyclic compounds. The obtained results confirmed the perspective of practical application of derivatives of pyrimidine, pyrazole, isoflavones, pyridine, oxazolopyrimidine and oxazole for acceleration of growth and development of flax (Linum usitatissimum L.) cultivars Ukrainian 3 and Svitanok during vegetative stage.

\section{References}

1. Oomah, B. D. (2001). Flax seed as a functional food source. Journal of the Science of Food and Agriculture, 81(9), 889-894. doi:10.1002/jsfa.898.

2. Wang Zh. (2012). Hobson N.The genome of flax (Linum usitatissimum) assembled denovo from short shotgun sequence reads. The Plant Journal, 72, 461-473.

3. Shim, Y. Y., Gui, B., Arnison, P. G., Wang, Y., \& Reaney, M. J. T. (2014). Flaxseed (Linum usitatissimum L.) bioactive compounds and peptide nomenclature: A review. Trends in Food Science \& Technology, 38(1), 5-20. doi:10.1016/j.tifs.2014.03.011.

4. Hall, L. M., Booker, H., Siloto, R. M. P., Jhala, A. J., \& Weselake, R. J. Chapter 6. Flax (Linum usitatissimum L.), In: Industrial Oil Crops, 1st Edn., 2016; 157-194.

5. Czemplik, M., Boba, A., Kostyn, K., Kulma, A., Mituła, A., \& Sztajnert, M. Wróbel- Kwiatkowska M., Żuk M., Szopa J. and Skórkowska-Telichowska K. Flax Engineering for Biomedical Application. In: Biomedical Engineering, Trends, Research and Technologies. S. Olsztynska (Ed.). InTech Publisher, 2011; 644.

6. Jhala, A. J., \& Hall, L. M. (2010). Flax (Linum usitatissimum L.):Current Uses and Future Applications. Australian Journal of basic and Applied Sciences, 4(9), 4304-4312.

7. Oil and Colour Chemists' Association. (1993). Surface Coatings. Raw Materials and Their Usage, 1, 610. doi:10.1007/978-94-011-1220-8.

8. Tomas, A. S., Akin, D., Foulk, J., \& Dodd, R. B. (2005). Effect of two growth regulators on yield and fiber quality and quantity in flax(Linum usitatissimum L.) [Plant Growth Regulator Society of America]. Quarterly, 33(3), 90-100.

9. Rastogi, A., Siddiqui, A., Mishra, B. K., Srivastava, M., Pandey, R., Misra, P., \& Shukla, S. (2013). Effect of auxin and gibberellic acid on growth and yield components of lin seed(Linum usitatissimum L.). Crop Breeding and Applied Biotechnology, 13(2), 136-143. doi:10.1590/S198470332013000200006.

10. Rehman, H., Nawaz, Q., Basra, S. M. A., Afzal, I., Yasmeen, A., \& Hassan, F. (2013). Seed Priming Influence on Early Crop Growth, Phenological Development and Yield Performance of Linola (Linum usitatissimum L.), Journal of Integrative Agriculture Advanced, Doi:10.1016/S20953119(13)60521-3.

11. Bakry, B. A., Tawfik, M. M., Mekki, B. B., \& Zeidan, M. S. (2012). Yield and Yield Components of Three Flax Cultivars (Linum usitatissimum L.) In Response to Foliar Application with Zn, Mn and Fe under Newly Reclaimed Sandy Soil Conditions Am-Euras. Journal of Agriculture and Environmental Sciences, 12(8), 1075-1080.

12. Emam, M. M., El-Sweify A.H., Helal, N.M. (2011). Efficiencies of some vitamins in improving yield and quality of flax plant. African Journal of Agricultural Research, 6(18), 4362-4369. doi:10.5897/AJAR11.1104. 
13. Janowicz, J., Niemann, J., \& Wojciechowski, A. (2012). The effect of growth regulators on the regeneration ability of flax (Linum usitatissimum L.) hypocotyl explants in in vitro culture. Bio Technologia, 93(2), 135-138.

14. Minn, K., Dietrich, H., Dittgen, J., Feucht, D., Häuser-Hahn, I., \& Rosinger, C. H. Pyrimidine derivatives and their use for controlling undesired plant growth, 2008, Patent US 8329717 B2.

15. Cansev, A., Gulen, H., Zengin, M. K., Ergin, S., Cansev, M., \& Kumral, N. A. Use of pyrimidines in stimulation of plant growth and development and enhancement of stress tolerance, 2016, Patent US 20160000075.

16. Nimbalkar, S., \& Hote, S. V. (2015). Pyrazole Derivatives and their Synthesis - A review. International Journal on Recent and Innovation Trends in Computing and Communication, 3(2), 6165 .

17. Dai, H., Li, Y. Q., Du, D., Qin, X., Zhang, X., Yu, H. B., \& Fang, J.-X. (2008). Synthesis and biological activities of novel pyrazole oxime derivatives containing a 2-chloro-5-thiazolyl moiety. Journal of Agricultural and Food Chemistry, 56(22), 10805-10810. doi:10.1021/jf802429x.

18. Miller M.J., Moraski G.C., Markley L.D., Davis G.E. Imidazo [1,2-a]pyridine compounds, synthesis thereof, and methods of using same, 2012, Patent US. 20120220457 A1.

19. Corsi C., Wendeborn S.V., Bobbio C., Kessabi J., Schneiter P., Grasso V., Haas U.J. Isothiazole and pyrazole derivatives for use as plant growth regulators, 2011, Patent EP 2358699A1.

20. Sergiev, I., Alexieva, V., Ivanov, S., Bankova, V., \& Mapelli, S. (2004). Plant Growth Regulating Activity of Some Flavonoids. Dokladi na Bulgarskata Akademiâ na Naukite, 57(4), 63-68.

21. Preedy, V. R. Isoflavones: Chemistry, Analysis, Function and Effects, CPI Group (UK). Ltd, Croydon, CR0 4YY, UK, 2013; 683.

22. Whittingham, W. G., Winn, C. L., Glithro, H., Boussemghoune, M. A., \& Aspinall, M. B. Pyrimidine derivatives and their use as herbicides, 2010; WO Patent 2010092339 A1.

23. Baum, J. S., \& Chen, T. M. Plant growth and development modification using benzoxazole derivatives, 1987; Patent US 4659360 A.

24. Chang, J. H., \& Baum, J. S. Phenylmethyl-4,4-dimethyl-3-isoxazolidinone plant regulators, 1990;Patent US 4892578 A.

25. Newton, T., \& Waldeck, I. Oxazole carboxamide herbicides, 2000; Patent US6096688 A.

26. Zhao, Q., Liu, S., Li, Y., \& Wang, Q. (2009). Design, Synthesis, and Biological Activities of Novel 2Cyanoacrylates Containing Oxazole, Oxadiazole, or Quinoline Moieties. Journal of Agricultural and Food Chemistry, 57(7), 2849-2855. doi:10.1021/jf803632t.

27. Saini, M. S., Kumar, A., Dwivedi, J., \& Singh, R. (2013). A review: biological significances of heterocyclic compounds [IJPSR]. International Journal of Pharma Sciences and Research, 4(3), 6677.

28. Quin, L. D., \& Tyrell, J. A. Fundamentals of heterocyclic chemistry: Importance in Nature and in the Synthesis of Pharmaceuticals. John Wiley \& Sons, Inc., Hoboken, New Jersey, 2010; 344.

29. Armenise D., Carocci A., Catalano A., Muraglia M., Defrenza I., De Laurentis N., Rosato A., Corbo F., and Franchini C. (2013). Synthesis and Antimicrobial Evaluation of a New Series of N-1,3Benzothiazol-2-ylbenzamides, Journal of Chemistry, Article ID 181758: 7.

30. Arshad, M., Khan, T. A., \& Khan, M. A. (2014). 1,2,4-triazine derivatives: Synthesis and biological applications. [IJPSR]. International Journal of Pharma Sciences and Research, 5(4), 149-162.

31. Griffioen, G., Coupet, L. M. E., Duhamel, H. R., Wera, S., \& Gomme, E. Thiadiazole derivatives for the treatment of neurodegenerative diseases, 2009; Patent US 20090054410 A1.

32. Shablykin, O. V., Kucharenko, O. P., Iakovenko, I. N., Yarmoluk, S. M., \& Brovarets, V. S. (2008). Search for specific protein kinase CK2 inhibitors and vasoactive compounds among 5-amino-1,3oxazoles derivatives. Ukrainica Bioorganica Acta, 1, 28-36.

33. Kopernik, I. M., Blagodatnyj, V. M., Petrenko, O. V., Kalashnikova, L. E., Prokopenko, V. V., Kondratyuk, K. M., \& Brovarets, V. S. (2011). Study in vitro for antimicrobic activity of new oxazole derivatives and products of its transformations. Ukrainica Bioorganica Acta, 2, 57-68.

34. Havrylyuk, D., Zimenkovsky, B., Vasylenko, O., Gzella, A., \& Lesyk, R. (2012). Synthesis of New 4Thiazolidinone-, Pyrazoline-, and Isatin-Based Conjugates with Promising Antitumor Activity. Journal of Medicinal Chemistry, 55(20), 8630-8641. doi:10.1021/jm300789g.

35. Zelisko, N., Atamanyuk, D., Vasylenko, O., Grellier, P., \& Lesyk, R. (2012). Synthesis and antitrypanosonal activity of new 6,6,7-trisubstituted thiopyrano[2,3-d]-[1,3]thiazoles. Bioorganic \& Medicinal Chemistry Letters, 22(23), 7071-7074. doi:10.1016/j.bmcl.2012.09.091. 
36. Havrylyuk, D., Zimenkovsky, B., Vasylenko, A., Day, G. W., Smee, D. F., Grellier, P., \& Lesyk, R. (2013). Synthesis and biological activity evaluation of 5-pyrazoline substituted 4-thiazolidinones. European Journal of Medicinal Chemistry, 66, 228-237. doi:10.1016/j.ejmech.2013.05.044.

37. Frasinyuk, M. S., Mrug, G. P., Bondarenko, S. P., Khilya, V. P., \& Brovarets, V. S. (2013). Antitumor activity of flavonoid Mannich bases. Ukrainica Bioorganica Acta, 2, 3-7.

38. Frasinyuk, M. S., Mrug, G. P., Bondarenko, S. P., Sviripa, V. M., Zhang, W., Cai, X., .. ., \& Watt, D. S. (2015). Application of Mannich Bases to the Synthesis of Hydroxymethylated Isoflavonoids As Potential Antineoplastic Agents. Organic \& Biomolecular Chemistry, 13(46), 11292-11301. doi:10.1039/C5OB01828E.

39. Bezverkha, I. S., Panteleimonova, T. M., Sharabura, L. B., Frasyniuk, M. S., \& Khylia, V. P. (2014). Antidepressant Effect Of Isoflavone 5/09 on Anxious Depression In Male Mice. Problems Aging and Longevity, 23(2), 101-112.

40. Tsygankova, V., Andrusevich, Ya., Shtompel, O., Hurenko, A., Solomyannyj, R., Mrug, G., \& Brovarets, V. (2016). Stimulating effect of five and six-membered heterocyclic compounds on seed germination and vegetative growth of maize(ZeamaysL.). International Journal of Biology Research, 1(4), 1-14.

41. Tsygankova, V., Andrusevich, Ya., Shtompel, O., Romaniuk, O., Yaikova, M., Hurenko, A., \& Brovarets, V. (2017). Application of Synthetic Low Molecular Weight Heterocyclic Compounds Derivatives of Pyrimidine, Pyrazole and Oxazole in Agricultural Biotechnology as a New Plant Growth Regulating Substances. International Journal of Medical Biotechnology \& Genetics, S2(002), $10-32$.

42. Tsygankova, V. A., Andrusevich, Ya. V., Shtompel, O. I., Kopich, V. M., Pilyo, S. G., Prokopenko, V. M., \& Brovarets, V. S. (2017). Intensification of Vegetative Growth of Cucumber by Derivatives of [1,3] oxazolo[5,4-d]pyrimidine and N-sulfonyl substituted of 1,3-oxazole [RJLBPCS]. Research Journal of Life Sciences, Bioinformatics, Pharmaceutical and Chemical Sciences, 3(4), 107-122.

43. Tsygankova, V., Andrusevich, Ya., Shtompel, O., Kopich, V., Solomyanny, R., Bondarenko, O., \& Brovarets, V. S. (2018). Phytohormone-like effect of pyrimidine derivatives on regulation of vegetativegrowth of tomato. International Journal of Botany Studies, 3(2), 91-102.

44. Tsygankova, V., Andrusevich, Ya., Kopich, V., Shtompel, O., Pilyo, S., Kornienko, A. M., \& Brovarets, V. (2018). Use of Oxazole and Oxazolopyrimidine to Improve Oilseed Rape Growth. Scholars Bulletin, 4(3), 301-312.

45. Tsygankova, V. A., Bayer, O. O., Andrusevich, Ya. V., Galkin, A. P., Brovarets, V. S., Yemets, A. I., $\&$ Blume, Ya. B. (2016). Screening of five and six-membered nitrogen-containing heterocyclic compounds as new effective stimulants of Linum usitatissimum L. organogenesis in vitro. International Journal of Medical Biotechnology \& Genetics, S2(001), 1-9.

46. Voytsehovska, O. V., Kapustyan, A. V., Kosik, O. I., Musienko, M. M., Olkhovich, O. P., Panyuta, O. O., \& Glorious, P. S. Plant Physiology: Praktykum, Lutsk: Teren, 2010.

47. Bang, H., \& Zhou, X. K. van Epps H.L., Mazumdar M. Statistical Methods in Molecular Biology. Series: Methods in Molecular Biology, New York: Humana press, 2010.

48. Miransari, M., \& Smith, D. L. (2014). Plant hormones and seed germination. Environmental and Experimental Botany, 99, 110-121. doi:10.1016/j.envexpbot.2013.11.005.

49. Hedden, P., \& Thomas, S. G. Plant Hormone Signaling, Oxford, UK: Blackwell Publishing Ltd, 2006.

50. Zhao, Y. (2010). Auxin biosynthesis and its role in plant development. Annual Review of Plant Biology, 61(1), 49-64. doi:10.1146/annurev-arplant-042809-112308.

51. Wang, Y. H., \& Irving, H. R. (2011). Developing a model of plant hormone interactions. Plant Signaling \& Behavior, 6(4), 494-500. doi:10.4161/psb.6.4.14558.

52. Sauer, M., Robert, S., \& Kleine-Vehn, J. (2013). Auxin: simply complicated. Journal of Experimental Botany, 64(9), 2565-2577. doi:10.1093/jxb/ert139.

53. Tsygankova, V. A., Galkina, L. A., Musatenko, L. I., \& Sytnik, K. M. (2005). Genetic and epigenetic control of plant growth and development. Genes of auxin biosynthesis and auxin-regulated genes controlling plant cell division and extension. Biopolymers and Cell, 21(2), 107-133. doi:10.7124/bc.0006E2. 